\title{
Composition, productivity and impact of grazing on the biodiversity of a grazing land in Almora District
}

\author{
Prem Prakash $^{1^{*}}$ and A.K . Paliwal ${ }^{2}$ \\ ${ }^{1}$ Department of Botany, Govt. P.G. College, Dwarahat, Almora (Uttarakhand), INDIA \\ ${ }^{2}$ Department of Botany, Govt. P.G. College, Bageshwar (Uttarakhand), INDIA \\ *Corresponding author. E-mail: drpp_bot@yahoo.co.in
}

\begin{abstract}
Biodiversity of Almora district is heavily affected in the areas with heavy grazing pressure, although moderate grazing enhanced the biodiversity of the area. In the present study site a total of 45 herbaceous species were present and therophytes were dominant among them. Live shoot biomass of plants varied from $175.0 \pm 3.5$ to $1862.0 \pm 5.75 \mathrm{~kg} / \mathrm{ha}$ and $87.0 \pm 3.25$ to $1303.0 \pm 7.50 \mathrm{~kg} / \mathrm{ha}$ in ungrazed and grazed plots respectively. Aboveground primary productivity was significantly higher on control plot $(3082.2 \mathrm{~kg} / \mathrm{ha})$ over grazed plot $(2644.0 \mathrm{~kg} / \mathrm{ha})$. The average bite frequency per hour was recorded maximum for goats (1106.5 bite/hr) and least for buffalos (920 bites/ hr). The monthly dry matter consumption per animal was amounted to $157.15,154.51,68.66$ and $61.34 \mathrm{~kg}$ for cow, buffalo, sheep and goat respectively under nomadic open grazing. The percent herbage exploitation was observed maximum by sheep $(9.82 \%)$ and minimum by buffalo $(8.75 \%)$.
\end{abstract}

Keywords: Bite frequency, Consumption, Phenology, Phenophases, System transfer function

\section{INTRODUCTION}

Loss of biodiversity is the single most important threat to the conservation and sustainable use of grazinglands in India due to many centuries of cultivation and heavy livestock grazing pressure. The livestock population has increased during the recent past and the problem of grazing has acquired serious dimensions, as a result the vegetative cover is decreasing which has resulted in the loss of top soil due to excessive erosion.

Overgrazing may eventually lead to the loss of vegetative cover. This predisposes the area to soil erosion and even landslides. Many natural types of grassland have been destroyed by cultivation or modified by grazing from livestock (Watkinson and Ormerod, 2001). Increasing population and corresponding demands of fodder and fuel have paralyzed our forest ecosystems. Floristic composition is one of the major anatomical characters of the plant community (Dansereau, 1960). Estimation of the biomass and productivity is a pre-requisite for understanding the properties and functions of ecosystem (Singh and Singh, 1992). The rich diversity of Almora district is now severely threatened and many species have become endangered. In this zone flock of animals travels the same route daily where the area has already been grazed by the first arrivals and thus makes severe and unplanned grazing. Due to the fact, various ecological parameters of this zone have been affected seriously. Although pivotal in grassland management, plant responses to grazing are sometimes difficult to predict. The aim of present study is to evaluate the floristic composition, production potential, consumption by different animals and impact on biodiversity by grazing practices on a meadow of temperate zone.

\section{MATERIALS AND METHODS}

Study area: The study was conducted during the years 2009-2010 near Suraiketh located in district Almora (Latitudes $30^{\circ} 22^{\prime}-30^{\circ} 14^{\prime}$ and Longitudes $78^{\circ} 56^{\prime}-78^{\circ} 47^{\prime}$ ), $20 \mathrm{~km}$ north of Dwarahat, Uttarakhand, India extending from 1200-1500 $\mathrm{m}$ above mean sea level. The region comprises temperate zone of Himalaya with Pinus as dominant tree species with graminoides as predominant under canopy vegetation and therefore, used as grazing land by local inhabitants. The study area consists of well-covered grazingland being exploited by the villagers of Suraiketh, Bitholi, Talli Bitholi, Kande, Walna, Naarh, Narsingh, Bawan, Banoli, Phaldwari and Bayela.

The study was conducted at two different sites in their degree of disturbance: Ungrazed site extending over an area of $200 \mathrm{~m}$ x $100 \mathrm{~m}$, has been permanently fenced by stone wall to avoid any type of domestic animals since 2005. The grazed plot with an area of 5 ha was exposed to extensive grazing. The livestock of these inhabitants mainly include cow, bullock, goat, buffalo and rarely sheep. Generally, each household owns 3-5 cattles. However, goats and sheep are owned by few households as a self employment option. The climate of the area is warm-temperate with moderate summers and severe winters with an annual precipitation of $960 \mathrm{~mm}$, most of 
which commences during the rainy season.

M ethodology: Study area was surveyed for floristic composition throughout the year 2009-10. All the species were collected followed by herbarium preparation and identification was done by the help of regional floras (Naithani, 1984, Gaur, 1999) and were crossed checked with Kumaun University Herbarium, Botanical Survey of India (BSI) and Northern circle herbarium at Dehradun. In the present study the assessment of total net productivity (TNP) is based on studying the increase in plant biomass employing the short term harvest method (Odum, 1960). This method measures directly the total net productivity minus losses due to consumption by insects and decay. Total net production (TNP) is the sum of aboveground net production and belowground net production and is usually estimated by the short-term harvest method. The aboveground net production has been calculated by summing the positive monthly increments in the standing crop (Singh and Yadava, 1974). The positive changes in the aboveground biomass on successive sampling dates are summed. The increment in the standing dead for only those sampling intervals during which a positive difference occurred in aboveground biomass are summed. Total of the two sums is considered as the net aboveground production. Belowground net production was estimated by summation of the significant positive increases in the belowground biomass on successive sampling dates throughout the study period. Consumption and herbage exploitation was estimated by the method used by Pandey (1981).

\section{RESULTS}

The total number of herbaceous species collected during the study year was 45 in both the plots. Out of these species 37 were present in the ungrazed plot and 28 species in the grazed plot. The total numbers of families found at the study site were 19 , and out of these 12 were dicotyledonous and 7 were of monocotyledonous. In the study area with 11 species, Poaceae was the dominant family followed by Asteraceae which had 9 species (Table 1).

In the ungrazed plot the biological spectrum was represented by $48.64 \%$ therophytes, $18.91 \%$ chamaephytes and hemicryptophytes each, $8.10 \%$ geophytes and 5.40 $\%$ phanerophytes. In the grazed plot life form spectrum was represented by $53.57 \%$ therophytes, $14.28 \%$ chamaephytes, $25 \%$ hemicryptophytes, $3.57 \%$ geophytes and phanerophytes each.It is interesting to see that the therophytes dominated both of the study sites.

Plant live shoot biomass varied considerably during different months. The values varied from $175.0 \pm 3.5$ to $1862.0 \pm 5.75 \mathrm{~kg} / \mathrm{ha}$ and $87.0 \pm 3.25$ to $1303.0 \pm 7.50 \mathrm{~kg} / \mathrm{ha} \mathrm{in}$ ungrazed and grazed plots respectively. From September onwards the biomass values declined due to mortality and transfer of live standing shoot material to standing dead and litter compartments. In general, total aboveground live crop was positively related to rainfall and total density of the plants (Table 2).

Aboveground primary productivity was significantly higher on control plot $(3082.2 \mathrm{~kg} / \mathrm{ha})$ over grazed plot $(2644.0 \mathrm{~kg} / \mathrm{ha})$. Aboveground live standing crop contributed 1862.0 and $1303.0 \mathrm{~kg} / \mathrm{ha}$ in control and grazed plots respectively, to the total aboveground primary production. Belowground net primary productivity was found significantly higher in control plot $(2452.0 \mathrm{~kg} / \mathrm{ha})$ than in grazed plot (1208.0 kg/ha) (Table 2).

Results of dry matter dynamics, based on average annual standing crop exhibit that live green biomass contributed 1180.5 and $817.75 \mathrm{~kg} / \mathrm{ha}$, standing dead contributed 269.5 and $368.5 \mathrm{~kg} / \mathrm{ha}$ and litter contributed 177.25 and 160.87 $\mathrm{kg} / \mathrm{ha}$ in control and grazed plots respectively. Total aboveground compartment showed dry matter dynamics of 1627.25 and $1347.37 \mathrm{~kg} / \mathrm{ha}$, total underground compartment showed 1425.87 and $890.00 \mathrm{~kg} / \mathrm{ha}$, total community dry matter dynamics was 3053.12 and 2237.37 $\mathrm{kg} / \mathrm{ha}$, underground disappearance was 1453.00 and $1217.00 \mathrm{~kg} / \mathrm{ha}$ and litter disappearance was 16.00 and nil $\mathrm{kg} / \mathrm{ha}$ annually in control and grazed plots respectively (Table 3).

System transfer function calculated for both the plots indicate that total solar radiation was found to be 2769 $\mathrm{J}$ oule $/ \mathrm{m}^{2} /$ day for both the sites. Gross primary productivity was calculated to be 7194.2 and $4707.6 \mathrm{~kg} / \mathrm{ha}$ for control and grazed plots. From this total GPP, $0.23 \%$ and $0.24 \%$ energy is transferred to environment through respiratory loss in control and grazed plots respectively. From total net primary productivity, 0.55 and $0.44 \%$ transferred to aboveground and 0.58 and $0.43 \%$ to underground component in control and grazed plots. Disappearance from litter and roots was noted at the rate of 0.03 and $0.59 \%$ respectively in control plot and 0.45 and $0.89 \%$ respectively in grazed plot (Fig. 1).

The bite frequency for all animals was higher during morning and evening hours of the day. The average bite frequency was greatest for goats (1106.5 bites/hour) followed by sheep (1090.2 bites/hr) and least for buffalo ( $920 \mathrm{bites} / \mathrm{hr}$ ). The variation of bite frequency in different months depends mainly on the availability of aboveground biomass (Table 4).

The average monthly dry matter consumption per animal was amounting to $157.15 \mathrm{~kg}$ for cows, $154.51 \mathrm{~kg}$ for buffalos, $68.66 \mathrm{~kg}$ for sheep and $61.34 \mathrm{~kg}$ for goat (Table 5 ). The aboveground standing crop was found positively correlated with dry matter consumption of the animal groups. The topography of the hills also indirectly affected the dry matter consumption. For example, buffalo did not reach to the fodder available on steep slopes or 


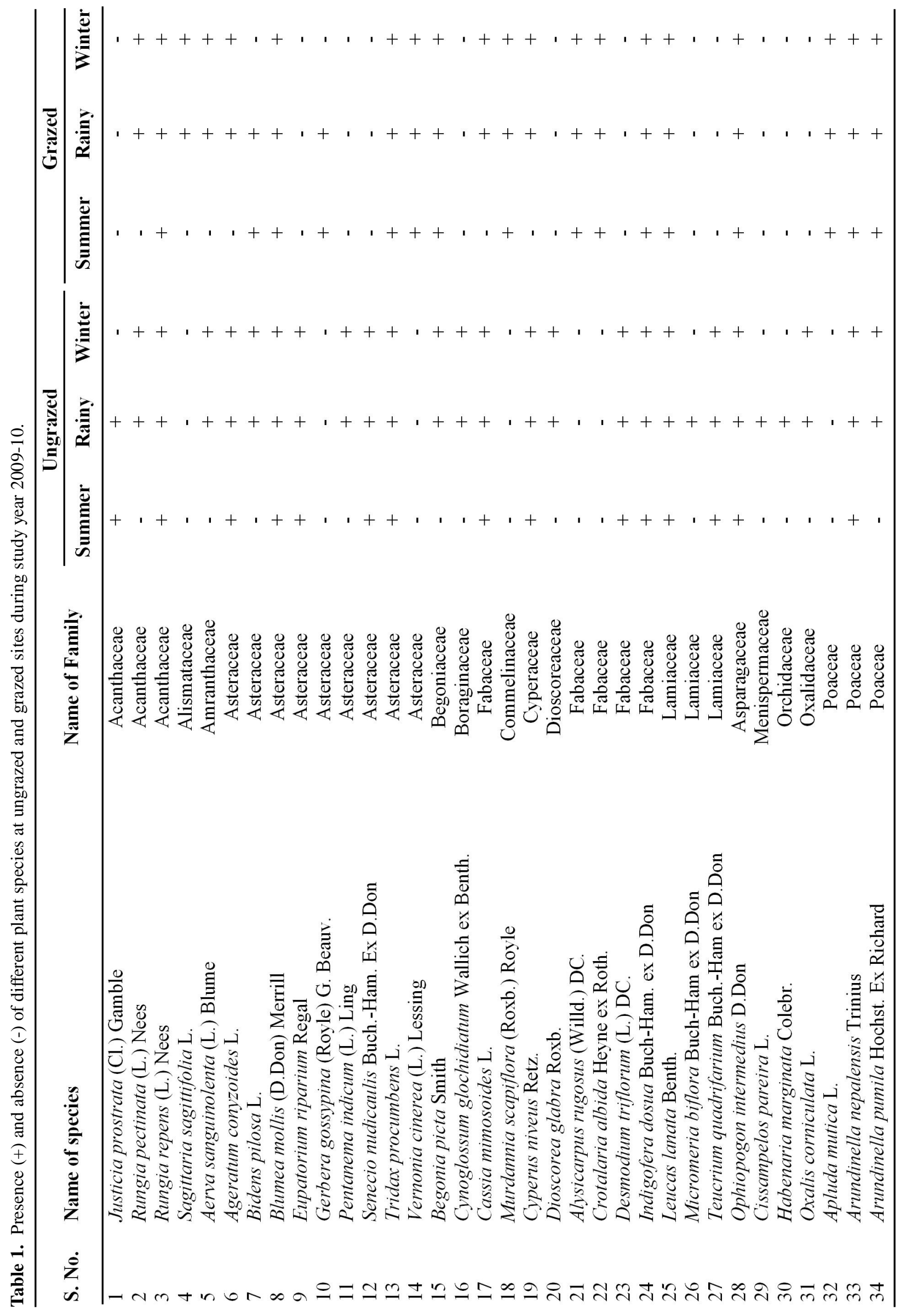




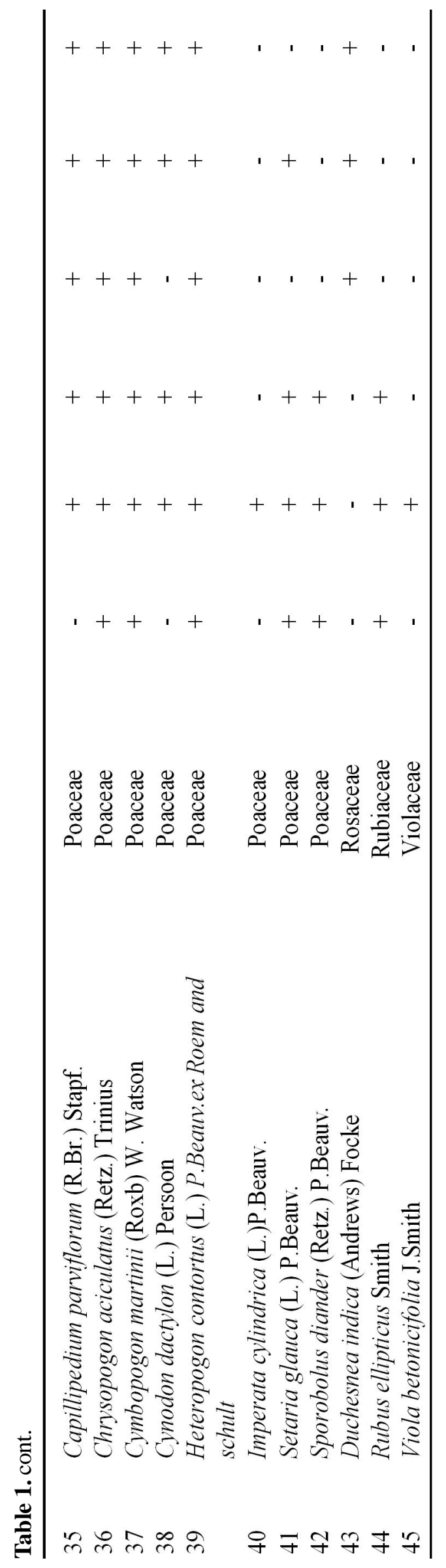

ridges. However, goats had access to all topographic sites and consumed most dry matter available. The average maximum percentage of herbage exploitation was observed for sheep (9.82) followed by cows (9.13). However the minimum values were recorded for buffalos (8.75).

During the course of study it was evident that more number of species were present in the ungrazed plot and less in frequently grazed plot due to regular disturbances.

\section{DISCUSSION}

Relatively small response of the plant community to grazing provides an opportunity to address some broad questions concerning relationships among responses of structural and functional aspects of systems in general. The vegetation of the present study site comprises typical temperate herbs and in floristic survey Poaceae is the widely represented family with $11 \mathrm{spp}$. The preponderance of therophytes in the area under investigation may be due to grazing and trampling. However the role of therophytes is difficult to resolve because of their near equal percentage in ungrazed (48.64\%) and grazed (53.57\%) plots respectively. Singh (1969) explained that higher number of therophytes is the identification of the amount of influence (man and animals) on habitats.

Floristic composition is a measure of species diversity and species number was highest during the rainy season in both the plots i.e., 37 species in ungrazed plot and 28 species in grazed plot (Table 1). Species diversity is commonly considered as an important ecological attribute of a natural organized community (Hairston, 1964).

The above-ground biomass in these grasslands varies from $1,000 \mathrm{~kg} / \mathrm{ha}$ to $10,000 \mathrm{~kg} / \mathrm{ha}$ for warm temperate grassland and $400-5,000 \mathrm{~kg} / \mathrm{ha}$ for high altitude grasslands (Gupta 1990). The amount of standing crop biomass in different compartments varied considerably in both the plots and sustained for varying length of time. The ungrazed plot has higher biomass values compared to the grazed plot. The biomass in each month increased with increasing amount of precipitation in growing season indicated optimum growing conditions (Sims and Singh, 1978). In the present study net accumulation of biomass increased from May and peaked in September. The results of present study are in conformity with the work of Ram et al., 1989. Belowground biomass in the present study decreased from April to July and increased again in August. Increase in biomass in August onwards could be due to higher translocation of organic matter and the accumulation of dead shoots (Rikhari and Negi, 1994).

The values of aboveground net primary productivity are comparable with the values reported for Central Himalayan grassland by Ram et al., 1989. Productivity for the belowground parts was higher than that of 


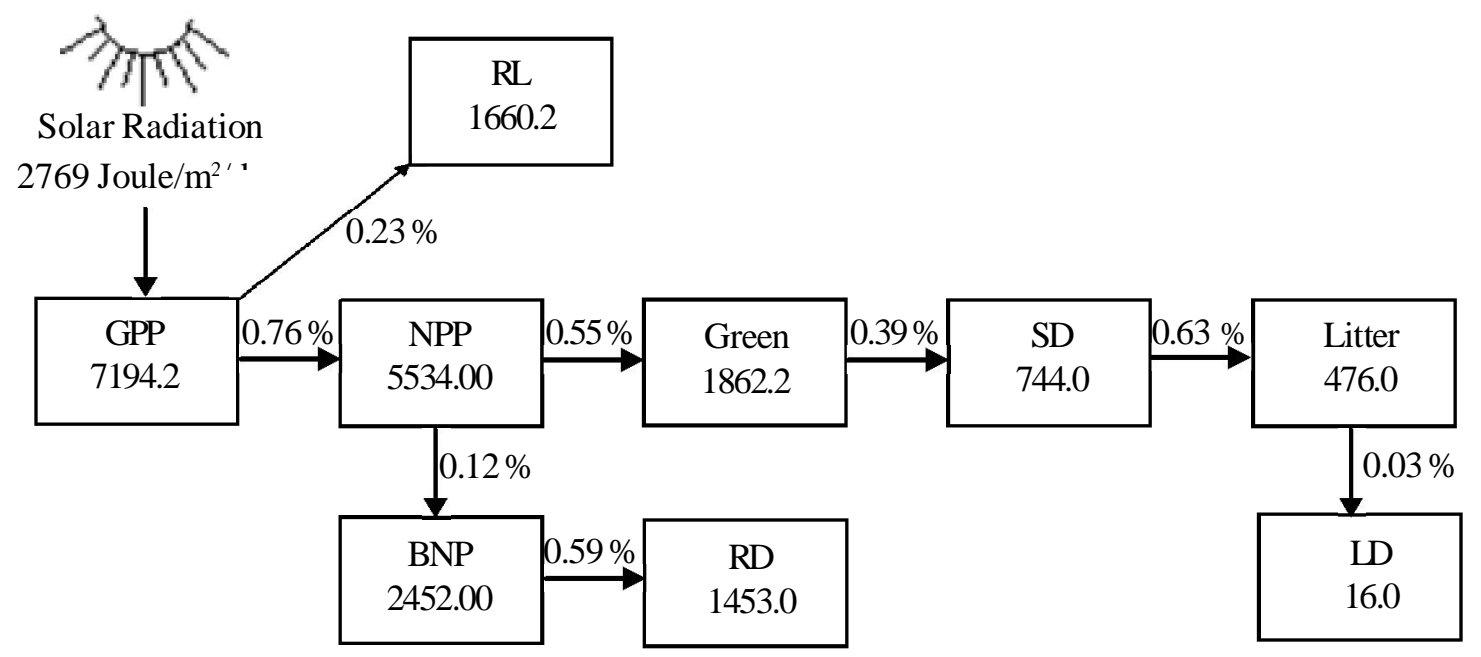

(A)

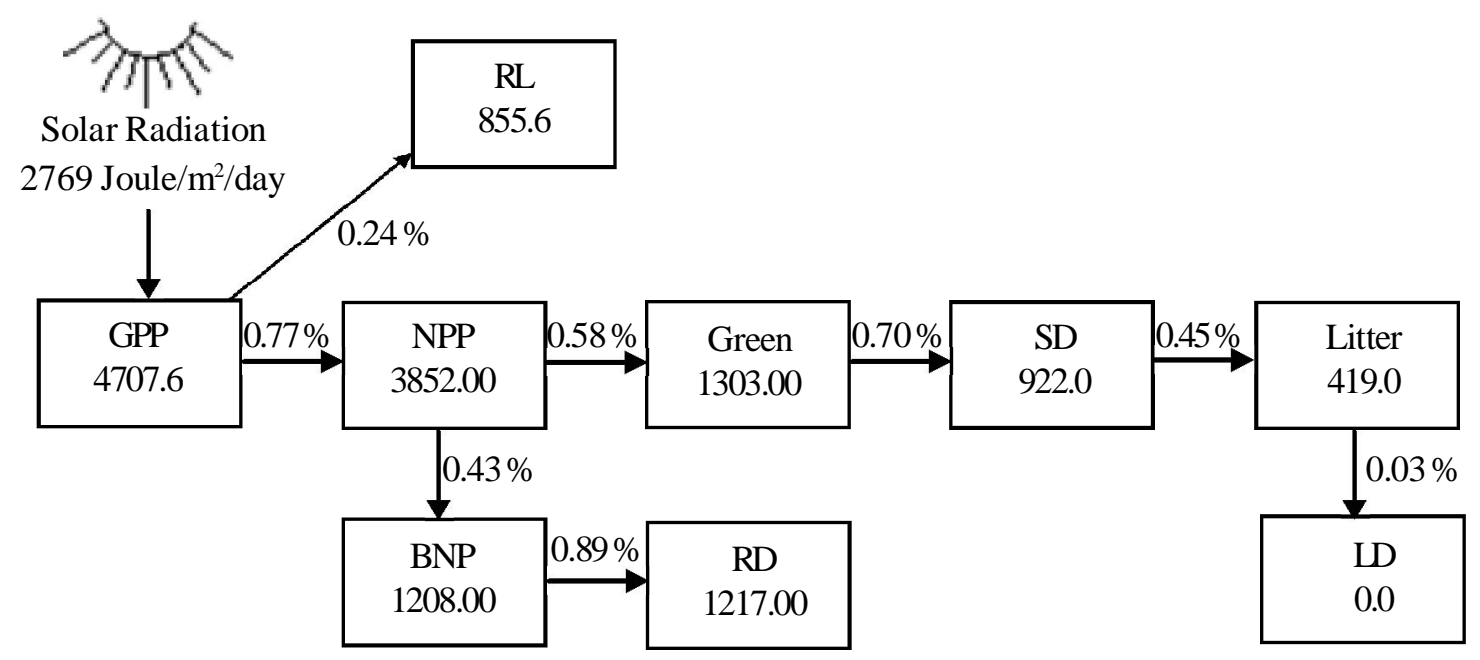

(B)

Fig. 1. Flow diagram of energy transfer through differ ent compartment at ungrazed (A) and grazed plot (B) (Values on arrow shows transfer rate and in box energy production) Abbreviations: ( GPP- G ross primary productivity, NPP - N et primary production, G reen-G reen biomass production, SD - Standing dead, BNP-B elowground net production, RD - Root disappearance, LD - Litter disappearance, RL- Respiratory Loss.

aboveground parts in the control plot but slightly lower in the grazed plot. Sims and Singh (1978) described that the photosynthatates are translocated downwards to storage region in the roots and thus help to increase the productivity of belowground parts. Lower values in grazed plot may be attributed to continuous removal of aboveground parts by heavy grazing which does not allow much of the photosynthatates to deposit in underground parts.

Heavy grazing pressure has been reported to reduce the diversity of herbs and shrubs in the range land (Zhao et al., 2006). Due to overgrazing, the vegetation species composition, richness and productivity has changed over the past decades, some species have disappeared, while others have survived through the use of morphological or other adaptations (Wang et al., 2002). The variation in bite frequency in different months depends upon the available biomass for grazing (Prakash, 2002). The data recorded for dry matter intake per bite for different animal groups are in conformity with the results of Sundriyal (1994) and Prakash (2002). The values of dry matter consumption by different animal groups indicate that the larger part of their daily requirement was being fulfilled from the open grazing. During rainy months animal movement is associated to active selection of forage due to plenty of herbage availability. Cattle seem to prefer on dicotyledons probably due to better forage quality, higher digestibility and good nutrient concentration particularly proteins and other minerals (Sundriyal and Joshi, 1992). The present study illustrates that the information on distribution, herbage production, animal consumption and exploitation of herbage by grazing animals was useful 
Table 2. Net production $(\mathrm{Kg} / \mathrm{ha})$ of different plant parts at ungrazed and grazed plots

\begin{tabular}{clcc}
\hline S. No. & Plant component & \multicolumn{2}{c}{ Net production(K g/ha) } \\
\cline { 3 - 4 } & & Ungrazed & Grazed \\
\hline 1 & Live green & 1862.00 & 1303.00 \\
2 & Standing dead & 744.00 & 922.00 \\
3 & Litter & 476.00 & 419.00 \\
4 & Total above ground production & 3082.00 & 2644.00 \\
5 & Total belowground production & 2452.00 & 1208.00 \\
6 & Total net production & 5534.00 & 3852.00 \\
\hline
\end{tabular}

Table 3. Dry matter dynamics (Kg/ha) based on average biomass of different plant components at ungrazed and grazed sites.

\begin{tabular}{llcc}
\hline S. No & Plant component & \multicolumn{2}{c}{ Dry matter dynamics (K g/ha) } \\
\cline { 3 - 4 } & & Ungrazed & Grazed \\
\hline 1 & Live green & 1180.50 & 817.75 \\
2 & Standing dead & 269.50 & 368.50 \\
3 & Litter & 177.25 & 160.87 \\
4 & Total above ground biomass & 1627.25 & 1347.37 \\
5 & Total belowground biomass & 1425.87 & 890.00 \\
6 & Total community biomass & 3053.12 & 2237.37 \\
7 & Underground disappearance & 1453.00 & 1217.00 \\
8 & Litter disappearance & 16.00 & 0.00 \\
\hline
\end{tabular}

Table 4. Average bite frequency $\left(\right.$ bite hour $^{-1}$ ) of animals in different months.

\begin{tabular}{clcccc}
\hline S. No. & M onth & Cow & Buffalo & Goat & Sheep \\
\hline 1 & March 2009 & $1030 \pm 15$ & $860 \pm 28$ & $1115 \pm 21$ & $1122 \pm 23$ \\
2 & May & $1070 \pm 27$ & $930 \pm 24$ & $1145 \pm 16$ & $1155 \pm 25$ \\
3 & July & $1090 \pm 22$ & $970 \pm 16$ & $1170 \pm 24$ & $1195 \pm 17$ \\
4 & September & $1110 \pm 19$ & $1010 \pm 19$ & $1195 \pm 21$ & $1160 \pm 18$ \\
5 & November & $1060 \pm 22$ & $940 \pm 21$ & $1060 \pm 18$ & $1015 \pm 22$ \\
6 & January 2010 & $980 \pm 27$ & $810 \pm 32$ & $960 \pm 25$ & $895 \pm 16$ \\
\hline
\end{tabular}

Table 5. Dry matter consumption (Kg/animal/month).

\begin{tabular}{llcccc}
\hline S. No. & M onth & Cow & Buffalo & Goat & Sheep \\
\hline 1 & March 2009 & $132.19 \pm 11.11$ & $126.18 \pm 7.71$ & $43.55 \pm 6.22$ & $55.70 \pm 6.15$ \\
2 & May & $163.45 \pm 9.23$ & $166.39 \pm 6.92$ & $65.74 \pm 5.35$ & $70.89 \pm 6.72$ \\
3 & July & $203.78 \pm 12.19$ & $193.31 \pm 9.32$ & $73.99 \pm 4.72$ & $87.76 \pm 7.12$ \\
4 & September & $204.44 \pm 7.23$ & $223.97 \pm 12.15$ & $87.76 \pm 7.22$ & $97.85 \pm 7.33$ \\
5 & November & $139.66 \pm 6.97$ & $141.62 \pm 6.72$ & $58.09 \pm 7.11$ & $58.52 \pm 7.74$ \\
6 & January 2010 & $99.40 \pm 12.23$ & $75.59 \pm 7.11$ & $38.93 \pm 7.19$ & $41.26 \pm 6.94$ \\
\hline
\end{tabular}

in assessing the present condition of grazing in temperate meadows. The temperate meadows available to the livestock are not yet sufficient to provide adequate fodder for the number of animals present for grazing (Agrwal and Dhasmana, 1989; McNaughton, 2001) and hence they are under great grazing pressure.

Livestock grazing reduces the dominance of aggressive species and increases the presence of species such as wheat grasses and needle grasses in native rangeland. In large native pastures where there is a diversity of plant species available, cattle can adjust their diets and select plants that may be more palatable and nutritious as the grazing season progresses. On large pastures there are likely sites of grazing such as heavy, moderate, lightly grazed or even ungrazed. This creates a wide range of habitat types for a variety of species moisture tolerance levels.

\section{Conclusion}

The present study site comprises typical temperate vegetation and in floristic survey maximum members belongs to family Poaceae. The preponderance of therophytes in the area under investigation may be due to grazing and trampling. Species diversity and species number were highest during the rainy season in both the plots. Aboveground primary productivity was significantly higher on control plot $(3082.2 \mathrm{~kg} / \mathrm{ha})$ over grazed plot $(2644.0 \mathrm{~kg} / \mathrm{ha})$. The variation in bite frequency in different months depends upon the available biomass for grazing. The average bite frequency was greatest for goats and least for buffalos. The present study illustrates that the information on distribution, herbage production, animal consumption and exploitation of herbage by 
grazing animals was useful in assessing the present condition of grazing in temperate meadows.

\section{REFERENCES}

Agarwal, A.K. and Dhasmana, R. (1989). Livestock grazing behaviour, consumption and percentage herbage exploitation. In a temperate grazingland of Western Himalaya. Intl. J our. Ecol. Env. Sci., 15: 171-180.

Dansereau, P. (1960). A combined structural and floristic approach to the definition of forest ecosystem. Silva F enn. $105: 16-21$.

Gaur, R.D. (1999). Flora of the District Garhwal N orth West Himalaya with Ethnobotanical Notes. Transmedia Publication, Srinagar Garhwal.

Gupta, S.K. (1990). Structure and functioning of grassland ecosystem in the Western Himalaya (Garhwal Himalaya). I. Altitudinal variation in carrying capacity. Tropical E cology. 31:1, 89-95.

Hairston, N.G. (1964). Studies on the organization of animal communities. J . Ecol., 52: 227-239.

McNaughton, S.J. (2001). H erbivory and Trophic Interactions. In: J. Roy, B. Saugier and H.A. Mooney (Eds.). Terrestrial Global Productivity: Past, Present, F uture. Academic Press, San Diego pp 101-122.

Naithani, B.D. (1984). Flora of C hamoli, G arhwal. Botanical Survey of India. 1-2, 789.

Odum, E.P. (1960). Organic production and turnover in oldfield succession. Ecology, 41:34-49.

Pandey, A.N. (1981). Vegetation and bovine population interaction in the savanna grazingland of Chandraprabha sanctuary, Varanasi. II. Seasonal behaviour of grazing aniamals and assessment of carrying capacity of the grazinglands. Tropical E cology, 22: 170-186.

Prakash, P. (2002). Composition, Productivity and Carrying Capacity of a Sub-Montane Grazingland of Garhwa Himalaya. D.Phil. Thesis, H.N.B. Garhwal University, Srinagar Garhwal, India. pp 219.

Ram, J., Singh, J.S. and Singh, S.P. (1989). Plant biomass, species diversity and net primary production in Central Himalayan High altitude grassland. J our. E col., 77: 456-468.
Rikhari, H.C. and Negi, GC.S. (1994). Structural and functional attributes of a tussock grass community in a Central Himalaya alpine grassland. In Pangtey, Y.P.S. and Rawat, R.S. (Eds) High altitudes of the Himalaya. (pp 193-202) Gyanodaya Prakashan, Nainital, India.

Sims, P.L. and Singh, J.S. (1978). The structure and function of ten Western North American grassland. II. Interseasonal dynamics in primary producer compartment. J. Ecol., 66: 547-572.

Singh, J.S. (1969). Influence of biotic disturbance on the preponderence and interspecific as sociation of two common forbs in the grasslands at Varanasi. India. Canadian J ournal of Botany, 47: 425-427.

Singh, J.S. and S.P. Singh (1992). F orest of H imalaya, Structure, Functioning and Impact of Man. Gyanodaya Prakashan Nanital.

Singh, J.S. and Yadava, P.S. (1974). Seasonal variation in composition, plant biomass and net primary productivity of a tropical grassland, India. E col. M onogr., 44: 351-376.

Sundriyal, R.C. (1994). Vegetation dynamics and animal behaviour in an alpine pasture in Garhwal Himalaya. In Pangtey, Y.P.S. and Rawal, R.S. (eds) High Altitudes of the Himalaya. Gyanodaya Prakashan, Nainital, India,pp 179192.

Sundriyal, R.C. and Joshi, A.P. (1992). Annual nutrient budget for alpine grassland in Garhwal Himalaya.J . Veg. Sci., 3: 21-26.

Wang, Y. S., Shiyomi, M., Tsuiki, M., Tsutsumi, M., Yu, X. R. and Yi, R. H. (2002). Spatial heterogeneity of vegetation under different grazing intensities in the Northwest Heilongjiang Steppe of China. Agriculture E cosystems and Environment, 90: 217-229.

Watkinson, A. R. and Ormerod, S. J. (2001). Grasslands, grazing and biodiversity:editors introduction. Journal of Applied E cology, 38: 233-237.

Zhao, W. Y., Li, J. L. and Qi, J.G. (2006). Changes in vegetation diversity and structure in response to heavy grazing pressure in the. Northern Tianshan Mountains, China. J ournal of Arid Environments, 68:337-508. 